\title{
Enzymatic Resolution of Ethyl 3-Hydroxy-3-Phenylpropanoate and Analogs using Hydrolases
}

\author{
Carlos M. R. Ribeiro ", Elisa N. Passaroto and Eugênia C. S. Brenelli \\ Departamento de Química Orgânica, Instituto de Química, Universidade Federal Fluminense, \\ Campus Valonguinho, 24020-150, Niterói - RJ, Brazil
}

\begin{abstract}
Este trabalho contribui com o estudo da relação substrato-modelo em reações de hidrólise de ésteres $\beta$-hidroxilados secundários e terciários. Foram utilizados um $\beta$-hidroxiéster secundário e quatro $\beta$-hidroxiésteres terciários, com as enzimas PCL, PLE, CRL e AOP. O melhor resultado foi obtido quando efetuou-se a reação enzimática do éster secundário 3-hidroxi-3-fenilpropanoato de etila (1a) com a PCL (50\% de conversão, éster (R)-1a recuperado com $98 \%$ e.e., e o ácido 1 obtido em 93\% e.e. Por outro lado, a PLE apresentou o melhor resultado para os ésteres terciários 3-hidroxi-3-fenilbutanoato de etila (2a) e 3-cicloexil-3-hidroxi-3-fenilpropanoato de etila (3a), apesar da baixa seletividade. PLE e CRL também foram avaliadas na resolução enzimática de 2-(1-hidroxicicloexil)-butanoato de etila (4a) e 2-(1-hidroxiciclopentil)-butanoato de etila (5a), entretanto, não apresentaram seletividade.
\end{abstract}

This work contributes to the substrate model study of enzymatic hydrolysis of secondary and tertiary $\beta$-hydroxy esters. One secondary and four tertiary $\beta$-hydroxy esters have been employed with PCL, PLE, CRL and AOP enzymes. The best result was observed when PCL was used as an enzyme for the reaction of the secondary ester, ethyl 3-hydroxy-3-phenylpropanoate (1a) (conversion of 50\%, ester (R)-1a recovered with $98 \%$ e.e. and the acid 1 with $93 \%$ e.e. On the other hand, PLE showed the best result for tertiary ethyl 3-hydroxy-3-phenylbutanoate (2a) and ethyl 3-cyclohexyl-3-hydroxy-3-phenylpropanoate (3a), despite the poor selectivity. Ethyl 2-(1-hydroxycyclohexyl)-butanoate (4a) and ethyl 2-(1-hydroxycyclopentyl)-butanoate (5a) were only hydrolyzed by PLE and CRL, but showed no enantioselectivity.

Keywords: $\beta$-hydroxy ester, enzymatic hydrolysis, hydrolases

\section{Introduction}

Enzyme catalysis has been one of the most useful methods for the preparation of enantiomerically pure compounds. Numerous studies have indicated the application of enzymes to prepare synthons for use in asymmetric synthesis and many reviews on this subject have been published recently ${ }^{1}$. Enzymes such as Pig liver esterase (PLE), Pseudomonas cepacia lipase (PCL), Candida rugosa lipase (CRL), Burkholderia cepacia lipase (BCL), and Aspergillus oryzae protease (AOP) have been used. Enzymes can be employed in the resolution of alcohols and esters and many examples have been reported in the literature ${ }^{1}$. The enzymatic hydrolysis of ethyl 3-hydroxy-3-phenylpropanoate (1a) or other ester derivatives to the 3-hydroxy3-phenylpropanoic acid (1) have interested several research groups. Acid $\mathbf{1}$ is an important intermediate in the synthesis of tomoxetine (I) and fluoxetine (II) hydrochlorides, widely used as antidepressants ${ }^{2}$ (Figure 1).

\footnotetext{
*e-mail: gqocmrr@vm.uff.br
}<smiles>O=C(O)CC(O)c1ccccc1</smiles>

1<smiles>Cc1ccccc1OC(CCNCCl)c1ccccc1</smiles>

I

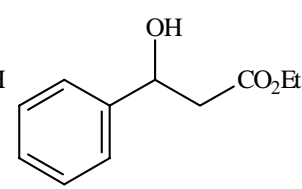

1a<smiles>CC(Cl)NCCC(Oc1ccc(C(F)(F)F)cc1)c1ccccc1</smiles>

II
Figure 1

To this end, $\mathrm{PLE}^{3}$ has been applied and more recently Pseudomonas $s p^{2}$ (Reaction 1). Penicillin GAmidohydrolase ${ }^{4}$ (PGA) and lipase $\mathrm{A}^{4 \mathrm{~b}}$ were also used in the hydrolysis of $\mathbf{1 a}$ O-acetyl derivative.

With PLE and at pH 7, a 50\% conversion was achieved, yielding ester (R)-1a in $28 \%$ (43\% e.e.) and (S)-acid 1c in 
<smiles>CCOC(=O)CC(O)c1ccccc1</smiles>

Reaction 1

$35 \%$ (39\% e.e.). Improved enantiomeric excess (58\% e.e. for (R)-1a and $46 \%$ e.e for (S)-acid $\mathbf{1}^{3}$ were achieved using $20 \%$ aqueous ethanol.

The hydrolysis of $\mathbf{1 a}$ in a phosphate buffer solution at pH 7 using lipase PS-30 from Pseudomonas sp (Amano), furnished (S)-acid 1 in 39\% conversion and $93 \%$ e.e. which was improved to $36 \%$ conversion of (R)-1a ( $98 \%$ e.e.), after two consecutive enzymatic hydrolysis ${ }^{2}$.

The hydrolysis of the acetyl ester of 1a using PGA at pH 8 in a phosphate buffer solution led to (R)-1a (36\% e.e. $)^{4 a}$. The hydrolysis of the same derivative using lipase A (Amano) led to ester (S)-1a (95\% e.e. $)^{4 b, 1 e}$.

These results prompted us to develop a complementary study on the resolution of $\mathbf{1 a}$ (prepared as stated in the literature by a classical Aldol reaction $)^{5}$, using the lipases from Pseudomonas cepacia and Candida rugosa, the protease from Aspergilus oryzae, as well as the esterase from Pig liver at $\mathrm{pH}$ 8 in a phosphate buffer solution to evaluate the best hydrolysis conditions.

In contrast to secondary alcohol synthesis, relatively few examples of the enzymatic resolution of more substituted systems have been reported ${ }^{6}$. As an extension of this work, the enzymatic resolution of ethyl 3-hydroxy3-phenylbutanoate (2a) and ethyl 3-cyclohexyl-3-hydroxy3-phenylpropanoate (3a), as well as ethyl 2-(1-hydroxycyclohexyl)-butanoate (4a) and ethyl 2-(1-hydroxycyclopentyl)-butanoate (5a) (Figure 2) were studied. These products were also obtained by aldol reactions.<smiles>CCC(=O)CC(C)(O)c1ccccc1</smiles>

2a<smiles>CCOC(=O)C(CC)C1(O)CCCCC1</smiles>

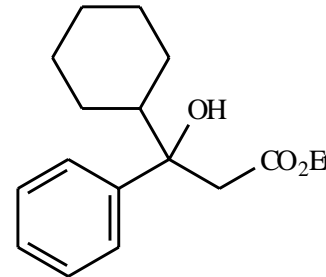

3a<smiles>CCCC(CC)C1(O)CCCC1</smiles>

Figure 2

\section{Experimental}

The solvents and reagents used were supplied by E. Merck or Aldrich Co. and THF was purified through a process of distillation over $\mathrm{LiAlH}_{4}$, according to standard laboratory techniques. Melting points were determined on a Fischer-Johns apparatus. Flash chromatography was performed using Kieselgel 60 (230-400 mesh, E. Merck). IR spectra were recorded on films or $\mathrm{KBr}$ pellets with a Perkin Elmer 1420 spectrometer. ${ }^{1} \mathrm{H} \mathrm{MNR}$ and ${ }^{13} \mathrm{C}$ NMR spectra were obtained in $\mathrm{CDCl}_{3}$ solutions $\left(\mathrm{Me}_{4} \mathrm{Si}\right.$ as internal standard) with a Varian Unity Plus 300 instrument. Whenever necessary, the e.e. was observed using tris-[3-heptafluoropropylhydroxymethylene)(+)-camphorato] europium (III) derivative $\left(\mathrm{Eu}(\mathrm{hfc})_{3}\right)$. Optical rotations were measured in $\mathrm{EtOH}$ or $\mathrm{CHCl}_{3}$ solutions with a Polartronic NH8 Schmidt/Haensch polarimeter at room temperature. The mass spectra were obtained with a VG Autoespec. Pig liver esterase (PLE, E3128, 300 units/mg protein, $15 \mathrm{mg}$ protein/mL suspension), Pseudomonas cepacia lipase (PCL, L9156, 90 units/g solid), Candida rugosa lipase (CRL, type VII, L1754, 835 units/mg solid) and Aspergillus oryzae protease (AOP, type XXIII, P4032, 3,6 units/mg solid) were purchased from Sigma Co.

Preparation of racemic $\beta$-hydroxy esters $1 \boldsymbol{a}, 2 \boldsymbol{a}, 3 \mathbf{3}, \mathbf{4 a}$ and $5 a^{5}$

General procedure: Under $\mathrm{N}_{2}$ atmosphere, $\mathrm{n}$-butyllithium (24 mmol) was added to a solution of diisopropylamine (3.7 $\mathrm{mL}, 26.4 \mathrm{mmol})$ and THF $(15 \mathrm{~mL})$ at $-78{ }^{\circ} \mathrm{C}$. The solution was stirred for $15 \mathrm{~min}$. The corresponding ethyl ester (22 mmol) was added dropwise to a solution of LDA and the reaction was conducted under stirring for $45 \mathrm{~min}$. After that, benzaldehyde or ketone was added dropwise. The mixture was stirred for $6 \mathrm{~h}$ at $-78^{\circ} \mathrm{C}$, and then treated with $\mathrm{NH}_{4} \mathrm{Cl}$ saturated solution and extracted with ethyl acetate. The organic layer was washed with water, saturated with $\mathrm{NaCl}$, and dried over $\mathrm{MgSO}_{4}$. The solvent was evaporated and the crude product was purified through chromatography on silica gel (n-hexane:ethyl acetate, 95:5).

Ethyl 3-hydroxy-3phenylpropanoate 1a9: 95\% yield; colorless oil; IR v $v_{\text {max. }} / \mathrm{cm}^{-1} 3450(\mathrm{OH}), 1720(\mathrm{CO}), 1190(\mathrm{CC})$ (film); ${ }^{1} \mathrm{H} \mathrm{NMR}\left(300 \mathrm{MHz}, \mathrm{CDCl}_{3}\right), \delta 1.27(3 \mathrm{H}, \mathrm{t}, J 7.2 \mathrm{~Hz})$, $2.70(1 \mathrm{H}, \mathrm{dd}, J 16.4$ and $4.8 \mathrm{~Hz}), 2.77(1 \mathrm{H}, \mathrm{dd}, J 16.4$ and 8.4 
Hz), 3.27 (br s, -OH), 4.18 (2H, q, $J 7.2 \mathrm{~Hz}), 5.13$ (1H, dd, $J$ 8.4 and $4.8 \mathrm{~Hz}), 7.26-7.40(5 \mathrm{H}, \mathrm{m}) ;{ }^{13} \mathrm{C}$ NMR $(75 \mathrm{MHz}$, $\left.\mathrm{CDCl}_{3}\right), \delta 14.0,43.2,60.8,70.2,125.6,127.7,128.4,142.4$, 172.3; EI-MS m/z (\%) 194 (32), 107 (100), 79 (59).

Ethyl 3-hydroxy-3-phenylbutanoate $\mathbf{2 a}^{10}$ : $80 \%$ yield; colorless oil; IR $v_{\max } / \mathrm{cm}^{-1} 3480,1720,1200$ (film); ${ }^{1} \mathrm{H}$ NMR (300 MHz, $\mathrm{CDCl}_{3}$ ), $\delta 1.13(3 \mathrm{H}, \mathrm{t}, J 7.2 \mathrm{~Hz}), 1.54(3 \mathrm{H}, \mathrm{s}), 2.79$ $(1 \mathrm{H}, \mathrm{d}, J 15.9 \mathrm{~Hz}), 2.98(1 \mathrm{H}, \mathrm{d}, J 15.9 \mathrm{~Hz}), 4.06(2 \mathrm{H}, \mathrm{q}, J 7.2$ $\mathrm{Hz}$ ), 4.41 (br, s, -OH), 7.20-7.47 (5H, m); ${ }^{13} \mathrm{C} \mathrm{NMR}(75 \mathrm{MHz}$, $\left.\mathrm{CDCl}_{3}\right), \delta 13.8,30.05,46.3,60.6,72.6,124.3,126.7,128.1$, 146.7, 172.6; EI-MS m/z (\%) 209 (7), 121 (100), 105 (77).

Ethyl 3-cyclohexyl-3-hydroxy-3-phenylpropanoate 3a ${ }^{11}$ : 75\% yield; colorless oil; IR $v_{\text {max. }} / \mathrm{cm}^{-1} 3480,1720$, 1200 (film); ${ }^{1} \mathrm{H}$ NMR (300 MHz, $\mathrm{CDCl}_{3}$ ), $\delta$ 0.97-1.77 $(12 \mathrm{H}, \mathrm{m}), 1.03(3 \mathrm{H}, \mathrm{t}, J 7.2 \mathrm{~Hz}), 2.85(1 \mathrm{H}, \mathrm{d}, J 15.6 \mathrm{~Hz})$, $3.01(1 \mathrm{H}, \mathrm{d}, J 15.6 \mathrm{~Hz}), 3.96(2 \mathrm{H}, \mathrm{q}, J 7.2 \mathrm{~Hz}), 7.18-7.49$ $(5 \mathrm{H}, \mathrm{m}) ;{ }^{13} \mathrm{C} \mathrm{NMR}\left(75 \mathrm{MHz}, \mathrm{CDCl}_{3}\right), \delta 13.7,26.2,26.9$, 42.2, 42.2, 48.6, 60.4, 77.1, 125.7, 126.5, 127.6, 144.9, 173.4; EI-MS m/z (\%) 276 (M+), 193 (95), 105 (100).

Ethyl 2-(1-hydroxycyclohexyl)-butanoate $\mathbf{4 a}^{12}: 80 \%$ yield; colorless oil; IR $v_{\max } / \mathrm{cm}^{-1} 3500,1715,1180$ (film); ${ }^{1} \mathrm{H}$ NMR (300 MHz, $\left.\mathrm{CDCl}_{3}\right), \delta 0.90(3 \mathrm{H}, \mathrm{t}, J 7.2 \mathrm{~Hz})$, 1.25-1.77 (11H, m), 1.29 (3H, t, $J 6.9 \mathrm{~Hz}), 2.34(1 \mathrm{H}, \mathrm{dd}, J$ 4.8 and $10.6 \mathrm{~Hz}), 4.20(2 \mathrm{H}, \mathrm{q}, J 6.9 \mathrm{~Hz}) ;{ }^{13} \mathrm{C} \mathrm{NMR}(75$ $\left.\mathrm{MHz}, \mathrm{CDCl}_{3}\right) \delta 12.2$, 14.2, 19.4, 21.6, 21.8, 25.6, 34.4, $37.4,56.2,60.2,71.5,176.4$.
Ethyl 2-(1-hydroxycyclopentyl)-butanoate $\mathbf{5 a}^{13}$ : 77\% yield; colorless oil; IR $v_{\text {max. }} / \mathrm{cm}^{-1} 3450,1710,1180$ (film); ${ }^{1} \mathrm{H} \mathrm{NMR}\left(300 \mathrm{MHz}, \mathrm{CDCl}_{3}\right) \delta 0.93(3 \mathrm{H}, \mathrm{t}, J 7.2 \mathrm{~Hz}), 1.40-$ $1.95(10 \mathrm{H}, \mathrm{m}), 1.30(3 \mathrm{H}, \mathrm{t}, J 7.2 \mathrm{~Hz}), 2.29(1 \mathrm{H}, \mathrm{dd}, J 3.9$ and $11.4 \mathrm{~Hz}), 2.50(1 \mathrm{H}$, br s, $-\mathrm{OH}), 4.20(2 \mathrm{H}, \mathrm{q}, J 7.2 \mathrm{~Hz})$; ${ }^{13} \mathrm{C} \mathrm{NMR}\left(75 \mathrm{MHz}, \mathrm{CDCl}_{3}\right) \delta 12.3,14.2,21.6,23.5,23.7$, $37.5,39.9,56.1,60.3,82.1,176.5$.

\section{Enzymatic hydrolyses}

General procedure: racemic esters 1a, 2a, 3a, 4a and 5a $(1 \mathrm{mmol})$ were combined with a phosphate buffer solution (10 mL) (Table 1 and 2) of $\mathrm{pH} 7$ or 8 and with enzyme (units; Table 1 or 2 ) under vigorous stirring at room temperature. The $\mathrm{pH}$ was maintained constant with the continuous addition of $0.25 \mathrm{~mol} \mathrm{~L}^{-1}$ aqueous $\mathrm{NaOH}$. After the indicated conversion (Table 1 and 2), the reaction was stopped. The reaction mixture was diluted with aqueous $\mathrm{NaHCO}_{3}$ and extracted three times with ether. The combined organic layers were dried $\left(\mathrm{MgSO}_{4}\right)$ and concentrated in order to obtain $1 \mathbf{a}, \mathbf{2 a}, \mathbf{3 a}, \mathbf{4 a}$ or $\mathbf{5 a}$, respectively (the \% yield and e.e. are presented in Table 1 and 2). The combined aqueous solution was acidified to pH 1 with $3 \mathrm{~mol} \mathrm{~L}^{-1} \mathrm{HCl}$ and extracted three times with ether. The extracts were dried $\left(\mathrm{MgSO}_{4}\right)$ and concentrated to obtain acid $1,2,3,4$ or 5 , respectively (the \% yield and e.e. are presented in Table 1 and 2).

Table 1. Enzyme-catalysed hydrolysis of racemic 1a at room temperature.

\begin{tabular}{|c|c|c|c|c|c|c|c|}
\hline Entry & $\begin{array}{l}\text { Enzyme } \\
\text { (unit) }\end{array}$ & Reaction time & $\mathrm{pH}$ & $\begin{array}{c}\text { Conversion } \\
(\%)\end{array}$ & $\begin{array}{l}\% \text { R-1a } \\
(\% \text { e.e. })^{\mathrm{b}}\end{array}$ & $\begin{array}{l}\% \text { S-1 }{ }^{\mathrm{a}} \\
(\% \text { e.e. })^{\mathrm{c}}\end{array}$ & $\begin{array}{l}\text { Acid }^{\mathrm{d}} \\
{[\alpha]^{22} \mathrm{D}}\end{array}$ \\
\hline 1 & PCL (0.45) & $6 \mathrm{~h}$ & 7.0 & 22 & $60(25)$ & $22(86)$ & -16.6 (c 0.482$)$ \\
\hline 2 & PCL (0.45) & $15 \mathrm{~h} 25 \mathrm{~min}$ & 7.0 & 40 & $59(62)$ & $39(>98)$ & $-19.2(c 1.140)$ \\
\hline 3 & PCL (0.45) & $21 \mathrm{~h}$ & 7.0 & 46 & $44(76)$ & $30(>98)$ & $-19.1(c 0.682)$ \\
\hline 4 & PCL $(0.45)$ & $43 \mathrm{~h}$ & 7.0 & 50 & $49(>98)$ & $47(93)$ & $-17.9(c 1.442)$ \\
\hline 5 & PCL (0.45) & $380 \mathrm{~h}$ & 7.0 & 68 & $22(>98)$ & $68(74)$ & $-14.3(c$ 1.112) \\
\hline 7 & PLE (50) & $40 \mathrm{~min}$ & 8.0 & 40 & $60(36)$ & $23(58)$ & $-10.9(c \quad 0.364)$ \\
\hline 8 & CRL $(75)^{e}$ & 17 day & 7.0 & 40 & $51(22)$ & $33(30)$ & $-5.9(c 0.670)$ \\
\hline 9 & $\operatorname{CRL}(150)^{\mathrm{e}}$ & 7 day & 7.0 & 40 & $60(15)$ & $32(40)$ & $-7.8(c 0.764)$ \\
\hline 10 & AOP (150) & 4 day & 7.0 & 34 & $50(37)$ & 34 (89) & $-17.4(c 0.684)$ \\
\hline 11 & AOP (720) & 2 day & 7.0 & 40 & $60(32)$ & $27(75)$ & $-14.5(c \quad 0.532)$ \\
\hline
\end{tabular}

a) determined on the basis of the sign of the specific rotation previously described ${ }^{2}$; b) e.e. determined by ${ }^{1} \mathrm{H} \mathrm{NMR} \mathrm{with} \mathrm{[Eu(hfc)}{ }_{3}$ ]; c) determined by $[\alpha]^{22}$; literature ${ }^{2}$ to $\mathrm{R}(+)-1,98 \%$ e.e. $[\alpha]^{22} \mathrm{D}+18.7$ (c 2.27, EtOH); d) solvent EtOH; e) value in $\mathrm{mg}$.

Table 2. Enzyme-catalyzed resolution of ester 2a and 3a using PLE

\begin{tabular}{|c|c|c|c|c|c|c|c|c|c|}
\hline Entry & Ester & $\begin{array}{c}\text { Enzyme } \\
\text { (unit) }\end{array}$ & $\begin{array}{l}\text { Reaction } \\
\text { time }\end{array}$ & $\mathrm{pH}$ & $\begin{array}{c}\mathrm{T} \\
\left({ }^{\circ} \mathrm{C}\right)\end{array}$ & $\begin{array}{c}\text { Conversion } \\
(\%)\end{array}$ & $\begin{array}{c}\text { Recovered R-estera; } \\
\text { yield }(\%) \\
(\% \text { e.e })^{\mathrm{b}}\end{array}$ & $\begin{array}{l}\text { S-Acida; } \\
\text { yield }(\%) ; \\
(\% \text { e.e. })^{\mathrm{c}}\end{array}$ & $\begin{array}{l}\text { Acid }^{\mathrm{d}} \\
{[\alpha]^{22} \mathrm{D}}\end{array}$ \\
\hline 1 & $2 \mathbf{a}$ & PLE (50) & $1 \mathrm{~h}$ & 8.0 & r.t. & 40 & 2a; $53(08)$ & $2 ; 30(50)$ & $+5.5(c 0.490)$ \\
\hline 2 & $2 \mathbf{a}$ & PLE (50) & $5 \mathrm{~h}$ & 8.0 & 3 & 22 & $2 a ; 61(03)$ & $2 ; 19$ (37) & $+4.1(c 0.490)$ \\
\hline $3^{e}$ & $2 \mathbf{a}$ & PLE (50) & $1.5 \mathrm{~h}$ & 8.0 & r.t. & 41 & 2a; 59 (09) & 2; 38 (48) & $+5.3(c 0.910)$ \\
\hline 4 & $3 \mathbf{a}$ & PLE (50) & 40 day & 8.0 & r.t. & 40 & 3a; $50(05)$ & 3; $32(00)$ & \\
\hline 5 & $2 \mathbf{a}$ & PCL $(0.45)$ & 29 day & 7.0 & r.t. & 00 & $\mathbf{2 a} ; 100(00)$ & $2 ; 00$ & \\
\hline 6 & $2 \mathbf{a}$ & PCL (0.90) & 8 day & 7.0 & r.t. & 00 & $\mathbf{2 a} ; 100(00)$ & $2 ; 00$ & \\
\hline 7 & 3a & PCL (0.45) & 3 day & 7.0 & r.t. & 00 & $\mathbf{3 a} ; 100(00)$ & 3; 00 & \\
\hline 8 & $3 a$ & CRL $(150)^{\mathrm{f}}$ & 7 day & 7.0 & r.t. & 32 & $\mathbf{3 a} ; 62(00)$ & 3; 00 & \\
\hline
\end{tabular}

a) determined based on the sign of the specific rotation previously described; b) e.e. determined by ${ }^{1} \mathrm{H} \mathrm{NMR} \mathrm{with}\left[\mathrm{Eu}(\mathrm{hfc})_{3}\right]$; c) determined by $[\alpha]^{22}{ }_{\mathrm{D}}$; literature ${ }^{10}[\alpha]^{22} \mathrm{D}+11.0($ c 3.004, EtOH); d) solvent EtOH; e) using DMSO as organic cosolvent, phosphate buffer: DMSO (9:1); f) value in mg. 
Esters 1a, 2a, 3a, 4a, and 5a: ${ }^{1} \mathrm{H}$ and ${ }^{13} \mathrm{C}$ NMR, IR, MS data, see above. The e.e. value and the $\%$ yield are presented in Table 1 and Table 2. To 1a ester at 50\% conversion $[\alpha]^{20}{ }_{\mathrm{D}}+44.2\left(c 1.01, \mathrm{CHCl}_{3}\right)$, literature ${ }^{2}[\alpha]^{20}{ }_{\mathrm{D}}$ $+44.0\left(c\right.$ 1.015, $\left.\mathrm{CHCl}_{3}\right)$, >98\% e.e..

3-Hydroxy-3-phenylpropanoic acid $\mathbf{1}^{2}$ : mp $115^{\circ} \mathrm{C}$; IR $\mathrm{v}_{\text {max. }} / \mathrm{cm}^{-1} 3450-2500,1700$ (film); ${ }^{1} \mathrm{H}$ NMR (300 MHz, $\left.\mathrm{CDCl}_{3}\right) \delta 2.78(1 \mathrm{H}, \mathrm{dd}, J 16.5$ and $3.9 \mathrm{~Hz}), 2.86(1 \mathrm{H}, \mathrm{dd}, J$ 16.5 and $9.0 \mathrm{~Hz}$ ), 3.80 (br s, $-\mathrm{OH}), 5.17(1 \mathrm{H}, \mathrm{dd}, J 9.0$ and $3.9 \mathrm{~Hz}), 7.28-7.41(5 \mathrm{H}, \mathrm{m}) ;{ }^{13} \mathrm{C} \mathrm{NMR}\left(75 \mathrm{MHz}, \mathrm{CDCl}_{3}\right)$, $\delta 44.0,70.3,125.9,127.4,128.4,144.8,172.2 ;$ EI-MS $\mathrm{m} / \mathrm{z}(\%): 166$ (54), 107 (100), 79 (83).

3-Hydroxy-3-phenylbutanoic acid $2^{10}$ : mp $52{ }^{\circ} \mathrm{C}$; IR $v_{\text {max. }} / \mathrm{cm}^{-1}$ 3480-2500, 1720 (film); ${ }^{1} \mathrm{H}$ NMR (300 MHz, $\left.\mathrm{CDCl}_{3}\right) \delta 1.55(3 \mathrm{H}, \mathrm{s}), 2.83(1 \mathrm{H}, \mathrm{d}, J 16.2 \mathrm{~Hz}), 3.02(1 \mathrm{H}$, d, $J 16.2 \mathrm{~Hz}$ ), 4.45 (br s, -OH), 7.22-7.44 (5H, m); ${ }^{13} \mathrm{C}$ NMR $\left(75 \mathrm{MHz}, \mathrm{CDCl}_{3}\right) \delta 30.4,45.8,72.7,124.2$, 127.0, 128.3, 146.1, 177.2; EI-MS $m / z$ (\%): 180 (11), 165 (100), 121 (56), 105 (28).

3-Cyclohexyl-3-hydroxy-3-phenylpropanoic acid $\mathbf{3}^{11}$ : mp $174{ }^{\circ} \mathrm{C}$; IR $v_{\max } / \mathrm{cm}^{-1} 3500-2600,1680$ (film); ${ }^{1} \mathrm{H}$ NMR $\left(300 \mathrm{MHz}, \mathrm{CDCl}_{3}\right) \delta 0.88-1.74(11 \mathrm{H}, \mathrm{m}), 2.90$ $(1 \mathrm{H}, \mathrm{d}, J 15.9 \mathrm{~Hz}), 3.06(1 \mathrm{H}, \mathrm{d}, J 15.9 \mathrm{~Hz}), 7.20-7.36(5 \mathrm{H}$, $\mathrm{m}) ;{ }^{13} \mathrm{C} \mathrm{NMR}\left(75 \mathrm{MHz}, \mathrm{CDCl}_{3}\right) \delta 26.1,26.3,26.4,26.7$, 26.9, 41.5, 48.7, 77.0, 125.5, 126.8, 127.8, 144.3, 177.3; EI-MS m/z (\%): 191 (34), 165 (79), 105 (100), 77 (31).

\section{Results and Discussion}

The hydrolysis of ester 1a using PCL, PLE, CRL and AOP enzymes were initially studied and the results are presented in Table 1.

The results observed in this work were similar to those obtained by Boaz ${ }^{2}$ and Santaniello ${ }^{3}$, where the Pseudomonas sp lipase was more active than PLE esterase, in the enzymatic ester 1a hydrolysis. These differences in the activities between these enzymes have been discussed elsewhere ${ }^{1 \mathrm{~g}}$.

As expected, the best result was achieved when PCL was used (Table 1). The hydrolysis of $\mathbf{1 a}$ at $50 \%$ conversion gave the remaining (R)-1a in $>98 \%$ e.e. and the (S)-acid $\mathbf{1}$ in $93 \%$ e.e. (entry 4 , Table 1 ).

Figure 3 shows the reaction curve for the ester hydrolysis, which demonstrates that the conversion rate decreased drastically after $50 \%$ of conversion. Our results showed that the ester hydrolysis could be carried out in a single step without successive reactions, as already mentioned. Similar conclusions were reached for the enzymatic acetylation of the 3-hydroxy-4-alkoxy methylbutanoate, as reported recently by Wunsche $e t a l^{7}$.

The results obtained from the hydrolysis of ester 1a

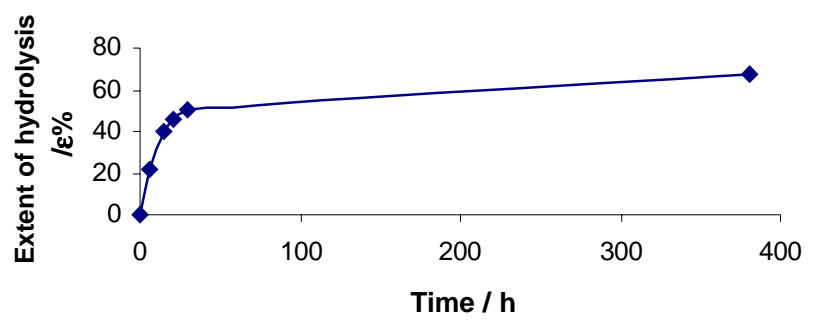

Figure 3. Extent of hydrolysis of racemic ester 1a by PCL lipase as a time function.

using PLE at pH 8 (entry 7, Table 1) were similar to those reported by Santaniello et $\mathrm{al}^{3}$. However, at $\mathrm{pH} 8$ a faster hydrolysis reaction was achieved compared with the data reported by Santaniello at $\mathrm{pH} 7$ (40 min versus $4 \mathrm{~h}$ ). The hydrolysis of 1a using AOP was comparable with PLE results, with a significant enhancement in the e.e. towards the recovered ester and the obtained acid (entry 10, Table 1). Compared with the other enzymes, CRL showed little enantioselectivity for the hydrolysis of $\mathbf{1 a}$ and a rather extended time of reaction (entry 8, Table 1).

Esters 2a and 3a were hydrolyzed with PLE, PCL and $\mathrm{CRL}$, under the same reaction conditions employed for ester 1a.

PLE at $\mathrm{pH} 8$ provided the best results (Table 2).

When PLE was used in the hydrolysis of $\mathbf{2 a}$ and $\mathbf{3 a}$, the recovered esters showed poor selectivity (entry 1 and 4, Table 2). (S)-acid 2 presented a modest e.e. (50\%), and acid 3 was racemic. DMSO was used as a cosolvent and the temperature was lowered in order to improve the results for the hydrolysis of 2a. Notwithstanding these modifications the results remained unsatisfactory (entry 2 and 3 , Table 2).

CRL (150 mg enzyme and $\mathrm{pH}$ 7) promoted the hydrolysis of $\mathbf{2 a}$. However, the products obtained were racemic. After 7 days at room temperature and a conversion of $32 \%$, the yields of recovered ester $\mathbf{2 a}$ and acid $\mathbf{2}$ were $62 \%$ and $32 \%$, respectively. Esters $\mathbf{2 a}$ and $\mathbf{3 a}$ were inert to PCL catalyzed hydrolysis under the same conditions of the 1a hydrolysis.

From the results presented in Tables 1 and 2, a decrease of the enantiomeric excess and an increase in the reaction time may be observed when an hydrogen on C-3 is replaced by methyl and cyclohexyl groups (entry 7 , Table 1 ; entry 1 and 4, Table 2), showing that for larger groups at C-3 the enzyme was not selective. There are useful models for acylated secondary alcohols and $\alpha$-substituted esters that predict which enantiomer will be faster hydrolyzed $1 \mathrm{~g}, \mathrm{k}, \mathrm{n}, \mathrm{o}, \mathrm{p}$. The importance of the groups at $\mathrm{C}-3$ concerning enzyme active site are discussed in some papers ${ }^{10}$, and using these models we can infer that bulkier groups at C-3 decrease the enzyme selectivity. The results corroborate the above 
assumption to the molecular modelling studies of the active site of these enzymes ${ }^{1 p}$.

PLE and CRL were also used in the hydrolysis of the $\beta$-hydroxy esters 4a and 5a. Although these enzymes promoted hydrolyses, only racemic esters and corresponding racemic acids were obtained under these conditions. When PLE (50 units) was employed for the ester hydrolysis of $\mathbf{4 a}$ at $\mathrm{pH} 8$ and at room temperature, the yield of recovered ester $4 \mathbf{a}$ was $42 \%$ and for the corresponding acid was $30 \%$ after 9 days at a conversion of $37 \%$. When CRL (150 mg) was used, the reaction time for ester $4 \mathbf{a}$ was 5 days at a conversion of $14 \%$ (the yield of recovered ester $4 \mathbf{a}$ was $11 \%$ ) and $2 \mathrm{~h}$ for ester $\mathbf{5 a}$ at a conversion of $15 \%$ (the yield of recovered ester $\mathbf{5 a}$ was $55 \%$ ), at $\mathrm{pH} 7$ at room temperature. These results showed that the presence of five and six member rings reduce the enzyme discrimination in these substrates, as observed for $\mathbf{2} \mathbf{a}$ and $\mathbf{3 a}$.

The results presented in this paper have added new data to the previously developed works ${ }^{2-4}$ and expand the scope of the estimation of the enzymes active sites through molecular modeling studies $1 \mathrm{p}$. The hydrolyses were carried out under different reaction conditions and other enzymes were employed. Four different $\beta$-hydroxy esters were also analyzed and the results obtained demonstrated the importance of the group size present at the $\beta$ carbon during the reaction, as above mentioned. Results confirm that PCL is a better enzyme to hydrolyze secondary $\beta$-hydroxy esters than PLE, CRL and AOP. On the other hand PLE, though depicting poor selectivity is more substrate specific. Experiments are in progress in our laboratory to improve the reactions conversions and selectivities.

\section{Acknowledgment}

This work was supported by CAPES and PADCT/CNPq.

\section{References}

1. (a) Roberts, S. M. Perkin 1 1999, 1; (b) Jones, J. B.; Desantis, G. Acc. Chem. Res. 1999, 32, 99; (c) Stecher, H.; Faber, K. Synthesis 1997, 1; (d) Schoffers, E.; Golebiowski, A.; Johnson, C. R. Tetrahedron 1995, 51, 3769; (e) Santaniello, E.; Ferrabosh, P.; Grisenti
P.; Manzocchi, A. Chem. Rev. (Washington, D. C.) 1992, 92, 1071; (f) Gupta, M. N. Eur. J. Biochem. 1992, 203, 25; (g) Kaslaukas, R. J.; Weissfloch, A. N. E.; Rappaport, A. T.; Cuccia, L. A. J. Org. Chem. 1991, 56, 2656; (h) Zhu, L. M.; Tedford, M. C. Tetrahedron 1990, 46, 6587; (i) Chen C. S.; Sih, C. J. Angew. Chem., Int. Ed. 1989, 28, 695; ( j) Whitesides, G. M.; Wong, C. H. Angew. Chem., Int. Ed. 1985, 24, 617; (k) Faber, K. In Biotransformations in Organic Chemistry; Springer-Verlag; Berlin, 1997; (1) Stecher, H.; Faber, K. Synthesis 1997, 1; (m) Azerad, R. Bull. Soc. Chim. Fr. 1995, 132, 17; (n) Lemke, K.; Lemke, M.; Theil, F. J. Org. Chem. 1997, 62, 6268; (o) Itoh, T.; Kuroda, K.; Tomasada, M.; Takagi, Y. J. Org. Chem. 1991, 56, 797; (p) Grabuleda, X.; Jaime, C.; Guerrero, A. Tetrahedron: Asymmetry 1997, 8, 3675

2. Boaz, N. W. J. Org. Chem. 1992, 57, 4289.

3. Santaniello, E.; Ferrabosh, P.; Grisenti, P.; Manzocchi, A.; Trave, S. Gazz. Chim. Ital. 1989, 119, 581.

4. (a) Baldaro, E.; D’Arrigo, P.; Fantoni, P.; Rosell, C. M.; Servi, S.; Tagliani, A.; Terreni, M. Tetrahedron: Asymmetry 1993, 4, 1031; (b) Kumar, A.; Dike S. Y.; Ner, D. H. Bioorg. Med. Chem. Lett. 1991, 1, 383.

5. Keukeleire, D. D.; Saeyens, W. Synth. Commun. 1996, 26, 4397.

6. (a) Feichter, C.; Faber, K.; Griengl, H. Perkin 1 1991, 653; (b) O'Hagen, D.; Zaid, N. A. Chem. Commun. 1992, 947; (c) Brackenridge, I.; McCague, R.; Roberts S. M.; Turner, N. J. Perkin 1 1993, 1093.

7. Wunsche, K.; Schwanenberg, U.; Bornscheur, U. T.; Meyer, H. H. Tetrahedron: Asymmetry 1998, 9, 3825.

8. Mohr, P.; Waespe-Sarcevic, N.; Tamm, C.; Gawronska, K.; Gawronski J. K. Helv. Chim. Acta 1983, 66, 2501.

9. Manzocchi, A.; Casati, R.; Fiecchi, A.; Santaniello, E.; Zhang,Y.; Wu,W. Tetrahedron: Asymmetry 1997, 8,3575 .

10. Kobayashi, M. Chem. Pharm. Bull. 1972, 20, 1898.

11. (a) Schjelderup, L.; Harbitz, O.; Groth, P.; Aasen, A. J. Acta Chem. Scand. B 1987, 41, 356; (b) Obata, S. J. Pharm. Soc. Jpn. 1953, 73, 1295.

12. (a) Duiding, A. S.; Pratt, R. J. J. Am. Chem. Soc. 1953, 75, 3717; (b) Miyashita, M.; Suzuki, T.; Hoshino, M.; Yoshikoshi, A. Tetrahedron 1997, 53, 12469.

13. Rathke, M. R. Org. React. 1975, $22,423$.

Received: June 19, 2000

Published on the web: August 10, 2001 